\title{
Usability of Mobile-Assisted Language Learning: Swedish Language Learning for Newcomers in Sweden
}

\author{
Samer Alkhouli ${ }^{1}$ \\ ${ }^{1}$ Örebro University School of Business, Sweden \\ Correspondence: Samer Alkhouli, Örebro University School of Business, Sweden. E-mail: \\ sameralkhouli@gmail.com \\ Received: August 27, 2018 \\ Accepted: September 20, 2018 \\ Online Published: October 12, 2018 \\ doi:10.5539/ijbm.v13n11p110 \\ URL: https://doi.org/10.5539/ijbm.v13n11p110
}

\begin{abstract}
The rapid advances of ICTs (Information and Communication Technologies) have enabled ease in accessible language acquisition through the use of a wide range of mobile devices. These devices can be used for language learning anywhere and at any time. Mobile-Assisted Language Learning (MALL) is one such approach to language acquisition. MALL is enhanced and managed through the support of modern mobile technological devices. The study objective is to investigate the newcomers' perspective in Sweden with regard to the usability of mobile devices in Swedish language learning. Additionally, this study will explore the newcomer's attitude towards language learning through mobile devices. An International Organisation for Standardisation (ISO 9241) approach was used in this study to investigate attributes associated with usability; efficacy, effectiveness and satisfaction. 11 newcomers to Sweden who learning Swedish at SFI (Swedish For Immigrants) were interviewed to comprehend their perspective concerning the usability of mobile devices in Swedish language learning. The discovered findings confirm that efficiency, effectiveness and satisfaction have significant positive rates among newcomers, toward mobile devices usability. Additionally, the newcomers use the mobile devices in daily activities more than they do for Swedish language learning.
\end{abstract}

Keywords: mobile-assisted language learning (MALL), usability, mobile devices, Swedish language learning, Swedish for immigrants (SFI)

\section{Introduction}

Due to the large number of people moving on a global basis, societies are facing an increasing influx of newcomers. Those who are voluntarily migrating generally come "for working purpose, for studying purpose, marriage...". Additionally, there is a vast number of impersonally organized migration (BBC, 2018; Bradley, Lindström, \& Hashemi, 2017; MacDonald \& MacDonald, 1964). For these newcomers, it is important to become integrated into the host society by learning its language (Driessen, van Emmerik, Fuhri, Nygren-Junkin, \& Spotti, 2011), so as not to be segregated and socially marginalised or excluded (Bradley et al., 2017; Rosén \& Bagga-Gupta, 2013). It is vital for newcomers to learn the local language so they can deal with the challenges relating to settling down in a new place and integrating into the host society in general (Brooker \& Lawrence, 2012). For a newcomer, knowing the language of the guest society would facilitate adapting to the new environment, as well as engaging in social interactions with locals (Morin, 2013).

\subsection{Background}

"If you talk to a man in a language he understands, that goes to his head. If you talk to him in his language, that goes to his heart". Nelson Mandela (Note 1)

The rapid advances of ICTs have enabled a wide range of mobile devices that can be used in language learning on the move, at any time (Harrison, Flood, \& Duce, 2013). Technology use in different learning activities allows for remote learning, thus giving rise to the concept of "E-learning" (Islam, Beer, \& Slack, 2015; Sarrab, 2015). Additionally, the use of specific devices for learning or education process at any given time or place is called M-learning (Ally, 2012; Chen, 2013; Sarrab, 2015). M-learning covers a variety of subjects and can be applied to any style of learning, depending on the mobile devices (Aizezi, 2015).

Mobile-Assisted Language Learning (MALL) is a new sub-term of M-learning and it is a unique approach to language acquisition which is enhanced and assisted through the support of modern mobile technological devices 
(Aizezi, 2015; Burston, 2016; Stockwell \& Hubbard, 2013). According to Viberg and Grönlund (2013), MALL refers to mobile devices used in learning language and it originates from the initial concept that introduced mobile learning, M-Learning (See Figure 1)

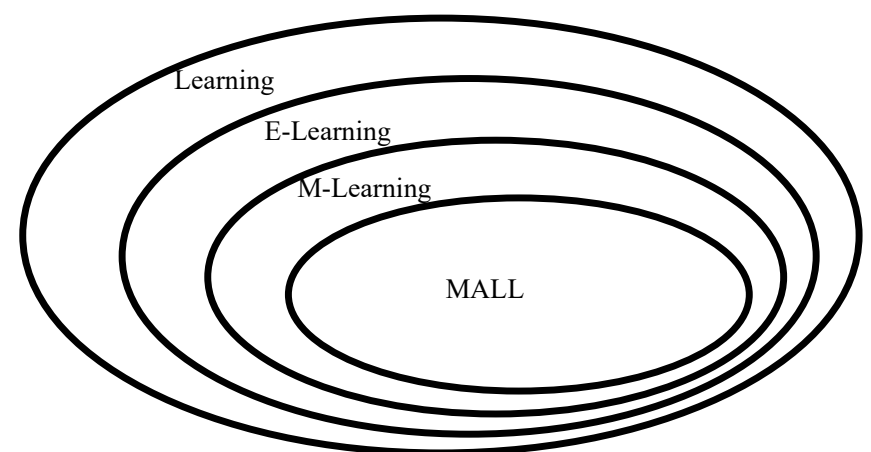

Figure 1. MALL as a subset of M-learning

Adapted from (Sarrab, 2015).

In this study, the term "mobile devices" will refer to all types of smartphones, tablets, laptops and Personal Digital Assistants (PDAs), as defined by literature and researchers' definition (Arain, Hussain, Rizvi, \& Vighio, 2017; Bradley et al., 2017; Levene \& Seabury, 2015; Yeap, Ramayah, \& Soto-Acosta, 2016). In addition to their small size, mobile devices provide many advantages, such as portability, accessibility, and usability, all of which support language learning (Aizezi, 2015; Burston, 2016; Viberg \& Grönlund, 2012). These devices are becoming ubiquitous among people and in daily life, as such, an effective way of putting them to use would be through language learning (Grant et al., 2015; Harrison et al., 2013).

\subsection{Research Question and Purpose of the Study}

\subsubsection{Usability of Mobile Devices}

"Usability" refers to the effortlessness with which mobile devices are made to function and is critical to the success of mobile devices and acceptance of mobile technology overall (Min, Li, \& Zhong, 2009; Urbaczewski \& Koivisto, 2007). The most widely recognised definition in literature for usability is "the extent to which a product can be used by specified users to achieve specified goals with effectiveness, efficiency and satisfaction in a specified context of use", coined by the International Organisation for Standardisation ISO 9241 (Bevan, Carter, \& Harker, 2015; Urbaczewski \& Koivisto, 2007). Usable devices are generally regarded as being efficient, easy to learn, effective in use, and enjoyable. Even more, they encompass another set of interests that is satisfying, entertaining, helpful and effective, such as creating systems (Kukulska-Hulme, 2004).

\subsubsection{Purpose of the Study}

The objective of this study is to investigate the perspective of newcomers in Sweden with regard to the usability of mobile devices in Swedish language learning. Additionally, this study seeks to explore newcomer attitudes with respect to the use of mobile devices in language acquisition.

\subsubsection{Research Question}

According to Kukulska-Hulme (2007), usability can be defined as a learning process that is unobstructed, effortless and enhanced. Approaching usability from this perspective and according to what was discussed in the previous sections, the following research question was formulated:

What are the newcomers' perspectives with regard to the usability of mobile assisted language learning for Swedish language learning?

For further clarification to the initial research question, a few sub-questions were set in place.

Firstly, "what are the newcomers' attitudes regarding using mobile devices for learning?", and secondly, "what challenges are they facing?"

\section{Literature Review}

In today's age, mobile devices have become quite ubiquitous and a necessity for most people. This change has resulted in a shift in attitudes toward language learning (Klímová, 2017; Urbaczewski \& Koivisto, 2007). 
According to the findings of a research conducted by Klímová (2017) concerning foreign language acquisition through mobile devices (2017), the use of mobile devices and their apps can result in positive effects on learning a foreign language, such as English, especially in the development of learners' vocabulary and pronunciation. Burston (2012) describes MobLang, a European project relating to MALL that was designed to teach languages (Spanish, English, Turkish and Greek). An analysis of their data proves that this project provided very positive results.

In an action research project conducted by (Chen, 2013), he investigates how students use mobile devices to learn the English language. The study demonstrates that mobile devices are ideal tools for creating an interactive and ubiquitous environment for language acquisition. This investigation also shows that students are satisfied with the usability and effectiveness of mobile devices used for MALL.

In a study conducted by (Bradley et al., 2017), 38 newcomers in Sweden participated in a government project relating to Swedish language learning. The results revealed that the use of mobile devices, both inside and outside the classroom, improved speech tempo and self-confidence in speaking. The participants also expressed an interest for more language training mobile apps.

In his thesis, Aizezi (2015) explores the usability issues of the mobile phone in Swedish language learning. The finding demonstrates that users viewed the usability of mobile devices in a positive light. Furthermore, the participants mentioned they are in favour of using mobile phones for Swedish language learning.

In their paper, Wong and Looi (2010) present two case studies of MALL in learning English prepositions and Chinese idioms. The study reveals that MALL has the potential of revolutionizing the language learning field by students' use of mobile devices as personal learning tools, inside and outside the classroom.

Many authors discussed the usability of devices and systems. The researchers used many models to investigate usability. Table 1 contains examples of usability models.

Table 1. Literature usability models

\begin{tabular}{ll}
\hline Author & Usability attributes \\
\hline Cyr, Head, and Ivanov (2006) & Design aesthetics, ease of use and usefulness \\
Burigat, Chittaro, and Gabrielli (2008) & $\begin{array}{l}\text { Task completion time, task duration and } \\
\text { accuracy }\end{array}$ \\
Urbaczewski and Koivisto (2007) & Satisfaction, ease of use, ease of learn \\
Hummel, Hess, and Grill (2008) & Delay and error rate \\
(Kim, Proctor, \& Salvendy, 2012) & Design, customer needs, satisfaction, \\
& innovativeness, feedback and efficiency \\
(Wu \& Wang, 2005) & Ease of use, usefulness and compatibility \\
\hline
\end{tabular}

\subsection{Study Model}

Usability for mobile devices is not radically different from the usability of other types of systems (Urbaczewski \& Koivisto, 2007). The ISO 9241 definition is utilised by numerous researchers in their studies such as works of (Bevan et al., 2015; Frøkjær, Hertzum, \& Hornbæk, 2000; Harrison et al., 2013; Huang, Chou, \& Bias, 2006; Hyvärinen, Kaikkonen, \& Hiltunen, 2005; Iso, 1998; Jeng, 2005; Min et al., 2009; Nah, Siau, \& Sheng, 2005; Nielsen, Overgaard, Pedersen, Stage, \& Stenild, 2006; Urbaczewski \& Koivisto, 2007), it is therefore suitable for this study. According to the ISO 9241 definition, and as mentioned in section 1.2.1., the three attributes that define usability are effectiveness, efficiency and satisfaction (Figure 2 illustrates this model).

Effectiveness is the accuracy and thoroughness with which users achieve specified objectives, as well as the ability of users to complete tasks. Effectiveness is measured by evaluating whether or not participants can complete a set of specified tasks. (Bevan et al., 2015; Harrison et al., 2013).

Efficiency is the ability to perform a certain task successfully, without wasting time and exerting extra effort (Aizezi, 2015). Efficiency is the resources (time, human effort, costs and material resources) that are expended when achieving a specific goal- e.g., the time to complete a specific task (Bevan et al., 2015; Harrison et al., 2013).

Satisfaction refers to the extent of comfort and positive feelings users attribute to a particular product while using it. It is the perceived level of agreeability and convenience afforded to the user (Aizezi, 2015; Bevan et al., 2015; Harrison et al., 2013). 


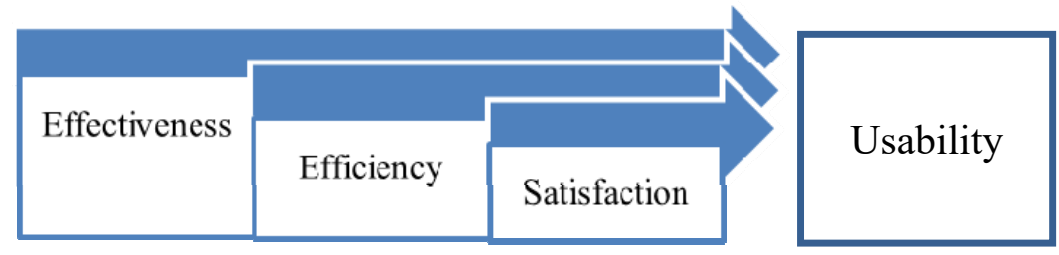

Figure 2. The study model

\section{Source: (author's own)}

After an overview of other literature in this field, this study aims to investigate how feasible is it for newcomers to use mobile devices to learn Swedish. The study measure usability of mobile devices to learn Swedish language with regard of newcomers' perspective in Sweden.

\section{Method and Framework}

In order to achieve this qualitative study's goal and to answer the research question, the three attributes of usability will be measured by conducting a series of semi-interviews with 11 participants, all of whom are newcomers to Sweden studying Swedish in SFI (Swedish For Immigrants) school (more details on SFI next sub-section).

According to the works of Dumas and Salzman (2006), the author chose to use interviewing as a tactic to collect the data. In their work, they mention four major categories of methods to measure usability. They were usability testing; usability inspections; surveys, interviews, and focus groups; and field methods. Dumas and Salzman highlighted some details to consider when using interview as a determining factor and these considerations are appropriate to this study. Some of these details were the complexity of the questions (relating to effectiveness and efficiency), small sample size, specific location of the interaction (SFI school), difficulty in acquiring a list of qualified respondents, and likelihood of unanswered survey questions. According to Kajornboon (2005), the author chose semi-structured interviews to allow for flexibility if needed, such as to rephrase questions, give explanations, ask for clarification, and to change the order of the questions if necessary.

\subsection{Participants and Data Collection}

The data were collected in the second week of April 2018 in Orebro city in the very heart of Sweden. The participants were 11 newcomers who were learning Swedish language in SFI school. Participants were selected randomly by selecting sample broadly representative of the Swedish language learner communities in Sweden among the newcomers. The author met with 5 of the interviewees in SFI school, 2 in Orebro university, and another 4 by phone. The appointments were scheduled according to the participants' convenience. The author has informed the participants that their identity will be kept anonymous, in addition the collected data will not be misused, and will use for this study only.

Established in 1965, SFI has been running a free, national Swedish language education programs for immigrants in Sweden for years. According to the new language act, anyone who is legally a resident in Sweden has the right to Swedish language education (Bradley et al., 2017; Rosén \& Bagga-Gupta, 2013).

The interviews contained 27 questions in five sections; participants' demographics information and background, effectiveness, efficiency, satisfaction and two open questions. The questions adapted from the works of (Aizezi, 2015; Chen, 2013; Lewis, 1995; Urbaczewski \& Koivisto, 2007). The questions were formatted according to their relevancy to the study's objectives and comprehensibility for participants.

\section{Data Analysis}

Followed (Burnard, 1991; Burnard, Gill, Stewart, Treasure, \& Chadwick, 2008) guidelines to analyse the data collected, the author recording the interviews verbatim, read the answers and exclude issues that are unrelated to the topic, took notes, and demanded verification by contacting interviewees through email and asking them to read their recorded answers and validate them.

\subsection{Result}

According to the structure of the interview questions, the author has organized the results in five categories; demographic information and background, effectiveness, efficiency, satisfaction and overall thinking. 


\subsubsection{Demographic Information and Background}

The participants were 6 males and 5 females between the ages of 18 and 58 years from diverse origins; Asia, Middle East, Europe, America and Africa. Their purpose of living in Sweden was for work opportunities, post-secondary studies, marriage, or migration. The research sample was broadly representative of the Swedish language learner communities in Sweden among the newcomers (Note 2). Almost all of the participants had the same purpose for learning Swedish language: to be able to communicate with the rest of society, and to understand and converse with Swedish people. In addition to that, some of them have special aims, such as finding a job or teaching their children. For example, one interviewee explained why she learns Swedish. She said: "I'm living in Sweden, so I need to learn Swedish. In addition, I need it for job and for daily activities." Another one explained, "I have to learn it to communicate with the society and teach my kids."

The participants use various types of mobile devices such as smartphones, tablets and laptops. Table 2 shows the research sample's demographics and the mobile devices used.

Table 2. The research sample's demographics, and mobile devices used

\begin{tabular}{|c|c|c|c|c|c|c|}
\hline & Gender & Age & Country & $\begin{array}{l}\text { Reason for stay in } \\
\text { Sweden }\end{array}$ & Devices used & Interview \\
\hline 1 & $\mathrm{~F}$ & 58 & Syria & Immigrant & iPhone X, iPad & Face to face \\
\hline 2 & $\mathrm{~F}$ & 35 & Syria & Immigrant & iPhone 7, iPad & Face to face \\
\hline 3 & $\mathrm{~F}$ & 39 & Bhutan & Study & $\begin{array}{l}\text { iPhone se, laptop MacBook } \\
\text { air }\end{array}$ & Face to face \\
\hline 4 & M & 35 & Uganda & Study & $\begin{array}{l}\text { Samsung Galaxy G5, laptop } \\
\text { Lenovo }\end{array}$ & Face to face \\
\hline 5 & $\mathrm{~F}$ & 25 & Japan & Marriage & iPhone 6, laptop Sharp & Phone \\
\hline 6 & M & 28 & Nepal & Working & Samsung S8. laptop Lenovo & Phone \\
\hline 7 & M & 29 & Germany & Study & iPhone 7, MAC laptop & Face to face \\
\hline 8 & M & 30 & Greece & Working & Sony Xperia XZ & Face to face \\
\hline 9 & M & 36 & Iraq & Immigrant & Samsung s4, laptop HP & Phone \\
\hline 10 & $\mathrm{~F}$ & 18 & Palestine & Immigrant & iPhone 7, iPad & Face to face \\
\hline 11 & M & 28 & $\begin{array}{l}\text { USA/Sweden } \\
\text { (Note 3) }\end{array}$ & Study & iPhone X & Phone \\
\hline
\end{tabular}

Internet connection is not an issue for any participant as Wi-Fi is available in school, at work and at home, however, not all interviewees had $3 \mathrm{G}$ or $4 \mathrm{G}$ connection. Two of the interviewees did not subscribe with this service, saying that they did not feel they needed it or simply for economic reasons. One interviewee stated:

"I do not need it [internet] outside, in addition to economic reasons." The other one said, "I don't need it because I have connection in the home and the class."

The majority of participants use the mobile devices outside learning times to communicate with friends and relatives, using social apps such as Facebook, WhatsApp, Viber, Line, Instagram, Twitter and LinkedIn. They spend between 3 to 8 (discontinuous hours) during a day using social apps. Additionally, participants had other programs and apps they use during the day, such as YouTube, Calendar, Mail, MS Office, Notes, Google translator and Music (see Table 3 in Appendix A for a brief description of these apps). During the interviews, the author observed that Facebook and WhatsApp have the most usage among the participants. As revealed by one participant "Facebook, WhatsApp, I use them about 6 to 8 hours in the day to contact with family and friends."

When studying, the participants use programs and apps for learning Swedish language, such as Fronter, Unis, Språkvägen, Kahoot, Duolingo, Google Translate, Lexin, YouTube and SVT Play (see Table 3 for a brief description of these apps). From the interviewees' explanations, the author observed that Google Translate and Fronter were most used among all apps and programs. Google Translate aids the students in familiarizing themselves with new vocabulary by translating new words to their mother tongue, and Fronter assists the students in organising and controlling the students' study in the SFI school. They spend between 15 minutes to 2 (discontinuous hours) in a day using learning programs. A student explains her activity in the school, saying:

"We use Unis and Språkvägen, those for reading, listing, writing and grammar. In addition to Kahoot, this to do entertainment competitions among students. I use Unis and Google translator for about one hour in the school." 
The primary feature used by participants to facilitate learning is the camera. Participants use the camera feature in their devices by taking photos or snapshots of documents and translating them. One interviewee explained,

"I use the camera to take a picture for the whiteboard when I don't have time to write everything, about one or two times in the class."

All the other utility-type apps come in second place, such as video, voice recording, weather, calendar, notes, mail and music features in the mobile devices. Participants use these features between 10 minutes to an hour in the SFI school. Outside school, they use translation services provided by Google or other apps and they watch SVT (Swedish TV) through the SVT Play app between 15 to 45 minutes in the day to enhance their listening and pronunciation.

In this section, the study's findings of demographics and background were presented, in addition to their attitudes regarding the use of mobile devices in Swedish language learning. According to the study's method, the next sub-sections will present the findings according to each of the usability aspects of mobile devices in Swedish language learning.

\subsubsection{Effectiveness}

The majority of the participants ( 7 out of 11) agreed that using mobile devices in Swedish language learning is effortless, does not need to be learned, and can be used comfortably. All participants, except one, stated that the use of mobile devices facilitates completing tasks and activities. The participant that disagreed only understood the Arabic language, and as a result, he faced some difficulties with utilising apps in English or Swedish language. He solved this problem by translating the words to Arabic and memorising them. He explained "I find some difficulties using mobile apps because I don't speak English, I speak only Arabic, and I'm still beginner in Swedish, so I need to translate some words to Arabic to understand and memorize them."

All participants agreed that using mobile devices for language learning is easy, and with some to little effort, the user can expertly operate the device. One participant explains why this is, saying: "the programs and apps were designed to be easy for all learners."

Using mobile devices helps participants learn Swedish without time constraints as the devices provide an effortless and convenient way to learn. As the participants explained, without the devices, they would need to go to the library and use books to find the information they need. They would also need to carry a dictionary everywhere and it would take them several minutes just to find one word. Instead, because of the great usability of mobile devices, one interviewee explained "When I translate word I can save it, and then I can use it again and learn it. And the app gives me the tenses for the verb, and how to pronounce it. Additionally, mobile devices allow for flexibility and accessibility, [as] the teacher cannot pay attention to all students in same time."

The devices enabled learners to accomplish learning tasks quickly, find the definitions of words and their pronunciations, and provide additional learning tools all in a matter of seconds, "To search for word meaning in a dictionary you need more than five minutes, but with mobile, I can translate it in seconds."

\subsubsection{Efficiency}

The time and effort spent by students using mobile devices in Swedish learning are considered essential to supporting their language acquisition. Some participants commented, "Man can learn language in the home as same as in the school using the mobile devices in learning." Another one stated, "I have old mobile phone, and old laptop, but even though using them, save my time in learning with little effort."

Using mobile devices in Swedish language learning is simple and does not require too much time or effort to learn. One participant recommends watching YouTube as an introduction to mobile learning. However, if the user has an old device, they might face some problems, such as charging, capacity and processing speed. One participant remarked, "...but one needs a modern device to not face problems in the device."

When asked to assess their progress, the participants rated their learning progress in Swedish language with high ratings. They came to this decision because "...using the mobile devices save $90 \%$ of my learning time" and "... if I didn't use the devices maybe I need several months to reach the same level which I'm in now." Overall, mobile assisted language learning seems to be an effective way to learn a new language.

Nonetheless, language educators and classes are still an important factor in the learning process. As one interviewee stated, “... the traditional way still required, because sometime there is problems with mobile, when you translate is not a good translation, sometimes wrong translation. Also, to understand the structure you need the traditional class," and also, "...but to learn Swedish you need to go to the class and talk with others and listen to teacher comments." 
While mobile devices facilitate language learning, there are still aspects of the language that need to be learnt in a classroom setting.

Ultimately however, the ease provided by mobile devices far outweighs any downsides to using them. From their small size and convenience, to their speed and efficiency, to their accessibility and mobility, mobile devices allow for an easy Swedish language learning experience - without any constraint on time or place. As one participant explained, "... using devices in learning is useful and easy, save time and can learn everywhere and anytime." Another one pointed out how, "... mobile and iPad size, mobility, accessibility and ability to use anytime and anywhere, internet connection available all the time, all those features make from the Swedish learning easy."

\subsubsection{Satisfaction}

Mobile devices inspire positive feelings in users when they use them in Swedish language acquisition. This feeling changes to pleasure when users are able to interact with the society using the assistance of their mobile devices, as one interviewee explained, “... I'm happy to use it. I feel pleasure when I learn new word and find meaning to word I don't know it before." This feeling will be felt at a reduced rate if users are operating an old device. In this case, they will suffer as they use it, as one participant who used an old smartphone complained, "I feel good when I translate and get meaning of the words, but I feel bad when my mobile stop working."

There are some programs and apps that facilitate language acquisition through a more entertaining approach, like Kahoot and Duolingo. All participants were satisfied using mobile devices in Swedish language learning, but this satisfaction can decrease depending on two factors as the participants clarified; the recentness of the mobile device model and the accuracy of translations. As one participant commented, "I'm satisfied, but sometime when you translate, and you get wrong translation, I'm not satisfied, and the teachers said to not rely to the translation all the time." Another one stated, "I'm satisfied, but I will be more satisfied if I have newer device."

Additionally, the participants were also satisfied with device functions like camera and connectivity as they found them very useful in learning process. One emphasized the importance of the features by saying, " ... without the functions in the device it will be like a normal phone. I use and carry it because of its functions." Another one went as far as to say, "The mobile devices became necessity, without them the learning will be difficult."

\subsubsection{Overall Thinking}

Two questions were included in the interview guide in order to allow participants describe their opinion in general about the usability of mobile devices assisted Swedish language learning.

According to all participants, mobile devices, nowadays, have become a necessary tool for Swedish language learning. With the assistance of mobile devices, the participants were able to learn and practise anytime and anywhere, translate when they go shopping or when they are talking to Swedish speakers, and listen and correct their pronunciation and more. As one participant illustrated, “... It's easy and accessible, I can find the translation when I make shopping, in the class, in the home. I can listen to the radio watch SVT from my laptop or my mobile. I can write, and the devices correct my writing. It's useful and convenient."

The participants did not find any clear disadvantages in using mobile devices to assist them in language learning. According to their discussion, technology is finding solutions for all emerging challenges and disadvantages. As one participant described, " $\ldots$ all challenges were solved, I have power bank for charging the mobile, the screen size is good enough, and I have internet connection everywhere. I don't have problems with the Swedish letters."

However, if the user has old device, he may still be able to find some disadvantages. One participant explained, “... the disadvantages are coming from old devices, charging battery, small screen size, slow processing and bad camera." According to another participant, there is one condition to user satisfaction and that is that the device should be modern, because otherwise, the functions will be slow or not working, "No, because they are slow and there are some functions not working."

\section{Discussion}

This study investigates the usability of mobile devices in Swedish language learning for newcomers in Sweden. The interviewees who took part in this research explained their perspectives concerning mobile assisted Swedish language learning in a significantly positive way, this in line with works of (Aizezi, 2015; Harrison et al., 2013; Klímová, 2017).

The research has resulted in important findings for both research and practice. Firstly, the usability of mobile devices in Swedish language learning has a positive review among the students in SFI, which is representative of 
all participants. The interviews have demonstrated the facility and effectiveness of mobile devices in language learning. Despite some difficulty in using programs in Swedish or English language, the participants can use the devices effectively and fulfil their tasks quickly (Al-Said, 2015; Chen, 2013). Mobile devices accessibility and mobility contributed in their efficiency in Swedish language learning (Anshari, Almunawar, Shahrill, Wicaksono, \& Huda, 2017; Yeap et al., 2016). Additionally, MALL encourages Swedish learning among students, helps in increasing students' performance and improves overall satisfaction in language learning (Arain et al., 2017; Chen, 2013). Effectiveness, efficiency and satisfaction of using mobile devices in Swedish learning depends on having a modern device and its ability to handle new technology and high connectivity speed (Anshari et al., 2017; Chen, 2013).

Secondly, participants spend most of their time using social apps on mobile devices to communicate with their relatives and friends. They use the devices between 6 to 8 hours during a day for non-learning purposes. In class or for language learning, they use the devices between 15 minutes to 2 hours, even though, at most, all they do during this time is translate words and texts with Google Translate. Other learning programs and apps do not have the same attention from students (Begum, 2011; Bradley et al., 2017; Stockwell \& Hubbard, 2013).

Thirdly, the students perceive that MALL enhances their Swedish language learning. This does not mean that owning mobile devices takes away the need for language educators and classes. This shows the advantage that mobile devices provide. With the use of mobile devices, students were able to learn new vocabulary in all tenses with the correct pronunciation (Chen, 2013; Klímová, 2017; Stockwell \& Hubbard, 2013). According to UNESCO working paper, the current pedagogical approaches are not ready enough to shift to mobile learning and begin a new generation of learning (Anshari et al., 2017; Vosloo \& West, 2012).

After discussing the three main findings of this study, the following subsections will be answering the research questions.

\section{Research Questions Answers}

What are the newcomers' perspectives with regard to the usability of mobile assisted language learning for Swedish language learning?

According to the study's method, usability of mobile devices in language learning has three aspects; effectiveness, efficiency, and satisfaction. The participants gave significantly positive feedback concerning this. Furthermore, it was clear that they rely on their mobile devices in their daily activities. Finally, newcomers used the mobile devices to communicate with the Swedish community, either by translating words (while shopping, at work, etc.) or by learning and practising the Swedish language.

Regarding the sub-questions: What are newcomers' attitudes regarding the use of mobile devices for learning? And what challenges are they facing?

The findings demonstrated that the newcomers use their mobile devices, firstly, to communicate with their relatives and friends, secondly, to learn through translating texts and receiving information about their learning progress through (e.g. the Fronter app), and to engage in some Swedish language practice and exercises. Lastly, the participants did not find any clear disadvantages in using mobile devices to assist them in language learning.

\section{Limitation}

In this study, calls and SMS messages were not included as features of mobile devices as learning methods, because not all mobile devices support calls or SMS. Additionally, the participants were 11 students. It would be enriching to this study if the participants had been more number.

\section{Conclusion}

In this study, 11 newcomers to Sweden who were learning Swedish were interviewed to better comprehend their perspective concerning the usability of mobile devices in Swedish language learning. The ISO 9241 approach was used to investigate attributes associated with usability; efficacy, effectiveness and satisfaction. The study's findings answer the research question by affirming that newcomers to Sweden do, in fact, have positive feeling toward mobile devices' usability, the newcomers use the mobile devices in daily activities more than they do for Swedish language learning. It would be advised that future studies explore additional perspectives with regard to the usability of mobile devices in Swedish language learning, specifically students and teachers. It may also help to investigate the opinions of the newcomers and teachers with respect to more specific dimensions of language learning through mobile devices, such as the usability of the language apps and programs.

\section{Acknowledgements}

I would like to express my gratitude to professor Annika Andersson for her invaluable guidance and assistance in 
this work. Appreciation is also extended to professor Mathias Hatakka for his invaluable instructions. In addition, I would like to thank all the other professors at Örebro University, who were encouraging and inspiring and providing necessary background to conduct this work.

\section{References}

Aizezi, Z. (2015). Identifying Mobile Phone Usability Issues in Informal Swedish Language Learning: What users think about it? (Master's Thesis), Uppsala University.

Ally, M. (2012). Mobile learning: The equalizer in education.La Educ@ ción Digital Magazine, 147, 1-13.

Al-Said, K. M. (2015). Students' perceptions of Edmodo and mobile learning and their real barriers towards them. TOJET: The Turkish Online Journal of Educational Technology, 14(2).

Anshari, M., Almunawar, M. N., Shahrill, M., Wicaksono, D. K., \& Huda, M. (2017). Smartphones usage in the classrooms: Learning aid or interference? Education and Information Technologies, 22(6), 3063-3079. https://doi.org/10.1007/s10639-017-9572-7

Arain, A. A., Hussain, Z., Rizvi, W. H., \& Vighio, M. S. (2017). An analysis of the influence of a mobile learning application on the learning outcomes of higher education students. Universal Access in the Information Society, 1-10.

BBC. (2018). Types of migration. Retrieved from http://www.bbc.co.uk/schools/gcsebitesize/geography/migration/migration_trends_rev2.shtml

Begum, R. (2011). Prospect for cell phones as instructional tools in the EFL classroom: A case study of Jahangirnagar University, Bangladesh. English Language Teaching, 4(1), 105. https://doi.org/10.5539/elt.v4n1p105

Bevan, N., Carter, J., \& Harker, S. (2015). ISO 9241-11 revised: What have we learnt about usability since 1998? Paper presented at the International Conference on Human-Computer Interaction.

Bradley, L., Lindström, N. B., \& Hashemi, S. S. (2017). Integration and language learning of newly arrived migrants using mobile technology. Journal of Interactive Media in Education, (1). https://doi.org/10.5334/jime.434

Brooker, A., \& Lawrence, J. A. (2012). Educational and cultural challenges of bicultural adult immigrant and refugee students in Australia. Australian Journal of Adult Learning, 52(1), 66.

Burigat, S., Chittaro, L., \& Gabrielli, S. (2008). Navigation techniques for small-screen devices: An evaluation on maps and web pages. International Journal of Human-Computer Studies, 66(2), 78-97. https://doi.org/10.1016/j.ijhcs.2007.08.006

Burnard, P. (1991). A method of analysing interview transcripts in qualitative research. Nurse education today, 11(6), 461-466. https://doi.org/10.1016/0260-6917(91)90009-Y

Burnard, P., Gill, P., Stewart, K., Treasure, E., \& Chadwick, B. (2008). Analysing and presenting qualitative data. British dental journal, 204(8), 429. https://doi.org/10.1038/sj.bdj.2008.292

Burston, J. (2012). Mobile language learning: Getting IT to work. Foreign language instructional technology, $81-99$.

Burston, J. (2016). Realizing the potential of mobile phone technology for language learning. IALLT Journal of Language Learning Technologies, 41(2).

Chen, X. B. (2013). Tablets for informal language learning: Student usage and attitudes.

Cyr, D., Head, M., \& Ivanov, A. (2006). Design aesthetics leading to m-loyalty in mobile commerce. Information \& management, 43(8), 950-963. https://doi.org/10.1016/j.im.2006.08.009

Driessen, M., van Emmerik, J., Fuhri, K., Nygren-Junkin, L., \& Spotti, M. (2011). ICT Use in L2 Education for Adult Migrants. A qualitative study in the Netherlands and Sweden.

Dumas, J. S., \& Salzman, M. C. (2006). Usability assessment methods. Reviews of human factors and ergonomics, 2(1), 109-140.

Frøkjær, E., Hertzum, M., \& Hornbæk, K. (2000). Measuring usability: are effectiveness, efficiency, and satisfaction really correlated? Paper presented at the Proceedings of the SIGCHI conference on Human Factors in Computing Systems. https://doi.org/10.1145/332040.332455 
Grant, M. M., Tamim, S., Brown, D. B., Sweeney, J. P., Ferguson, F. K., \& Jones, L. B. (2015). Teaching and learning with mobile computing devices: Case study in K-12 classrooms. TechTrends, 59(4), 32-45. https://doi.org/10.1007/s11528-015-0869-3

Harrison, R., Flood, D., \& Duce, D. (2013). Usability of mobile applications: literature review and rationale for a new usability model. Journal of Interaction Science, 1(1), 1. https://doi.org/10.1186/2194-0827-1-1

Huang, S.-C., Chou, I.-F., \& Bias, R. G. (2006). Empirical evaluation of a popular cellular phone's menu system: Theory meets practice. Journal of Usability Studies, 1(2), 91-108.

Hummel, K. A., Hess, A., \& Grill, T. (2008). Environmental context sensing for usability evaluation in mobile hci by means of small wireless sensor networks. Paper presented at the Proceedings of the 6th International Conference on Advances in Mobile Computing and Multimedia.

Hyvärinen, T., Kaikkonen, A., \& Hiltunen, M. (2005). Placing links in mobile banking application. Paper presented at the Proceedings of the 7 th international conference on Human computer interaction with mobile devices \& services.

Islam, N., Beer, M., \& Slack, F. (2015). E-learning challenges faced by academics in higher education. Journal of Education and Training Studies, 3(5), 102-112. https://doi.org/10.11114/jets.v3i5.947

Iso, W. (1998). 9241-11. Ergonomic requirements for office work with visual display terminals (VDTs). The international organization for standardization, 45, 9 .

Jeng, J. (2005). Usability assessment of academic digital libraries: effectiveness, efficiency, satisfaction, and learnability. Libri, 55(2-3), 96-121. https://doi.org/10.1515/LIBR.2005.96

Kajornboon, A. B. (2005). Using interviews as research instruments. E-journal for Research Teachers, 2(1), 1-9.

Kim, K., Proctor, R. W., \& Salvendy, G. (2012). The relation between usability and product success in cell $\begin{array}{llll}\text { phones. Behaviour \& } \quad \text { Information } & \text { 969-982. }\end{array}$ https://doi.org/10.1080/0144929X.2011.596997

Klímová, B. (2017). Mobile phones and/or smartphones and their apps for teaching English as a foreign language. Education and Information Technologies, 1-9.

Kukulska-Hulme, A. (2004). Usability: a common theme for developments in e-learning at the UK Open University. International Journal of Distance Education Technologies, 2(3), i-vi.

Kukulska-Hulme, A. (2007). Mobile usability in educational contexts: what have we learnt? The international review of research in open and distributed learning, 8(2).

Levene, J., \& Seabury, H. (2015). Evaluation of mobile learning: Current research and implications for instructional designers. TechTrends, 59(6), 46-52. https://doi.org/10.1007/s11528-015-0904-4

Lewis, J. R. (1995). IBM computer usability satisfaction questionnaires: psychometric evaluation and instructions for use. International Journal of Human-Computer Interaction, 7(1), 57-78. https://doi.org/10.1080/10447319509526110

MacDonald, J. S., \& MacDonald, L. D. (1964). Chain migration ethnic neighborhood formation and social networks. The Milbank Memorial Fund Quarterly, 42(1), 82-97. https://doi.org/10.2307/3348581

Min, Q., Li, S., \& Zhong, Q. (2009). An empirical study of m-commerce adoption from usability perspective. Paper presented at the Mobile Business, 2009. ICMB 2009. Eighth International Conference on.

Morin, A. (2013). Lin'guage: Self-Directed In-Country Language Learning for Cultural Integration. (Master's Thesis), Umeå University,

Nah, F. F.-H., Siau, K., \& Sheng, H. (2005). The value of mobile applications: a utility company study. Communications of the ACM, 48(2), 85-90.

Nielsen, C. M., Overgaard, M., Pedersen, M. B., Stage, J., \& Stenild, S. (2006). It's worth the hassle!: the added value of evaluating the usability of mobile systems in the field. Paper presented at the Proceedings of the 4th Nordic conference on Human-computer interaction: changing roles.

Rosén, J. K., \& Bagga-Gupta, S. (2013). Shifting identity positions in the development of language education for immigrants: an analysis of discourses associated with 'Swedish for immigrants'. Language, Culture and Curriculum, 26(1), 68-88. https://doi.org/10.1080/07908318.2013.765889 
Sarrab, M. (2015). M-learning in education: Omani Undergraduate students perspective. Procedia-Social and Behavioral Sciences, 176, 834-839. https://doi.org/10.1016/j.sbspro.2015.01.547

Stockwell, G., \& Hubbard, P. (2013). Some emerging principles for mobile-assisted language learning. The International Research Foundation for English Language Education, 1-15.

Urbaczewski, A., \& Koivisto, M. (2007). Measuring mobile device usability as a second order construct in mobile information systems. AMCIS 2007 Proceedings, 286.

Viberg, O., \& Grönlund, Å. (2012). Mobile assisted language learning: A literature review. Paper presented at the 11th World Conference on Mobile and Contextual Learning.

Viberg, O., \& Grönlund, Å. (2013). Systematising the field of mobile assisted language learning. International Journal of Mobile and Blended Learning (IJMBL), 5(4), 72-90. https://doi.org/10.4018/ijmbl.2013100105

Vosloo, S., \& West, M. (2012). UNESCO, Policy Guidelines for Mobile Learning. Paris, France: UNESCO.

Wong, L. H., \& Looi, C. K. (2010). Vocabulary learning by mobile-assisted authentic content creation and social meaning-making: two case studies. Journal of Computer Assisted Learning, 26(5), 421-433. https://doi.org/10.1111/j.1365-2729.2010.00357.x

Wu, J. H., \& Wang, S. C. (2005). What drives mobile commerce?: An empirical evaluation of the revised technology acceptance model. Information \& management, 42(5), 719-729. https://doi.org/10.1016/j.im.2004.07.001

Yeap, J. A., Ramayah, T., \& Soto-Acosta, P. (2016). Factors propelling the adoption of m-learning among students in higher education. Electronic Markets, 26(4), 323-338. https://doi.org/10.1007/s12525-015-0214-X

\section{Notes}

Note 1. Nelson Mandela president of South Africa (1994-1999). http://www.sahistory.org.za/people/nelson-rolihlahla-mandela

Note 2. According to some information the author has got from the Orebro municipality by e-mail.

Note 3. Participant number 11 is Swedish and has US nationality and grew up there. He joined SFI to learn his mother language Swedish.

\section{Appendix A}

Table 3. Discretion of some apps and programs for mobile devices usage

\begin{tabular}{|c|c|}
\hline Facebook & $\begin{array}{l}\text { Facebook.com, Facebook is a social networking site that makes it easy for you to connect } \\
\text { and share with your family and friends online }\end{array}$ \\
\hline WhatsApp & $\begin{array}{l}\text { WhatsApp is a messenger uses the internet to send messages, images, audio or video and making } \\
\text { calls }\end{array}$ \\
\hline Viber & Viber is a messaging app that connects people, audio and video calls, messaging and more \\
\hline Line & Calling and messaging app, audio and video \\
\hline Instagram & $\begin{array}{l}\text { Instagram is a free photo and video sharing app available on Apple iOS, Android and Windows } \\
\text { Phone. }\end{array}$ \\
\hline Twitter & Twitter is a social networking service and microblogging where you write messages, \\
\hline LinkedIn & LinkedIn is a web service and App where you can manage your professional network \\
\hline YouTube & $\begin{array}{l}\text { YouTube is a video community, that is, a site of videos uploaded with related discussions and } \\
\text { social media features. }\end{array}$ \\
\hline
\end{tabular}




\begin{tabular}{ll}
\hline Ms Office & Microsoft Office is an office suite, that is, a collection of software products for various office \\
Google & Gork. \\
translator & webpage to another language. \\
https://fronter.com/orebro/ Fronter is learning platform where student will find information about & courses, tutorials, homework and more \\
Fronter & Unis.nu Unis is a teaching tool, gives the student the opportunity to work more intensively with \\
UNIS & language learning whenever it suits. \\
SPRÅKVÄGEN & sprakvagen.se is a teaching tool for teachers and students, and have new methods for teaching \\
& with new structure \\
kahoot.it Create a fun learning game, can make a series of multiple choice questions, add videos, & images and diagrams to the questions to amplify engagement. \\
KAHOOT & Duolingo.com is a free language learning platform for Windows, Android and iOS. Fun and \\
science-based. Practice online or on the apps. \\
https://lexin.nada.kth.se/lexin/ it is machine translation of words, provide useful transilation \\
services \\
Is an app to see the SVT programs and broadcasts when and where it suits for the user. \\
\hline Lexin
\end{tabular}

Source: webpage - about, FQA, help.

\section{Copyrights}

Copyright for this article is retained by the author(s), with first publication rights granted to the journal.

This is an open-access article distributed under the terms and conditions of the Creative Commons Attribution license (http://creativecommons.org/licenses/by/4.0/). 